\title{
Ethical Outsourcing and the Act of Acting Together
}

Yue S. Ang, Ph. D.

Oxford Brookes University, United Kingdom

\begin{abstract}
The European Commission defines Corporate Social Responsibility as 'a concept whereby companies integrate social and environmental concerns in their business operations and in their interaction with their stakeholders on a voluntary basis' (European Commission, 2011, p. 3). Outsourcing affects the interests of laborers and ethical outsourcing protects their interests through the act of acting together ensuring that labor protection is a shared responsibility between the participants. An aspect of social philosophy helps rectify this problem by introducing ethical outsourcing that occurs upon fulfilling the combination of three features - (1) the inclusion of all participants in a joint activity. (2) All participants must agree to enter into a multi-lateral agreement. (3) The voluntarism of each participant practicing CSR is strengthened by the peer-to-peer demands of fulfilling these obligations. The empowerment of the participating organizations is incentivizing because of the engagement in participatory decision-making through the act of acting together.
\end{abstract}

Keywords: outsourcing, CSR, multi-lateral agreements, legitimate forgetting, empowerment, acting together, leadership.

\section{INTRODUCTION}

Corporate Social Responsibility (CSR) is a notion, which treats the stakeholders of businesses ethically or in a responsible manner (Hopkins, 2007). At its best, CSR is a multi-level phenomenon involving multiple actors from employees, consumers, management, institutional investors, pressure groups and the CSR-embracing business partners, jointly shaping the behavior of other corporations (Aguilera, Rupp, Williams \& Ganapath, 2007).CSR is defined as 'a concept whereby companies integrate social and environmental concerns in their business operations and in their interaction with their stakeholders on a voluntary basis (European Commission, 2011, p. 3). This integration of concerns promotes business sustainability as opposed to making profits, which requires the volition of pro-CSR actors (Drexhage \& Murphy, 2010).

A globalized world entails a convoluted network of these pro-CSR actors. This chapter argues that this convoluted network of pro-CSR actors dilutes their influence in non-CSR practicing corporations' behaviors. From here, it explores the method of outsourcing and suggests that CSR practices can thrive through the empowerment of pro-CSR actors and the act of acting together with non-CSR practicing corporations.

'Outsourcing' is the process whereby an outsourcer sub-contracts its tasks onto an outsourced partner. These tasks could be of any nature, and may involve numerous participants from many sectors. For example, a pair of trainers in the retail shop will have involved numerous participants working in logistics, warehouses, factories, plantations, and advertising. These participants might reside within the outsourcer's jurisdiction where outsourcing might be in the form of marketing, finance or research and development (Milberg \& Winkler, 2013). Or, they might reside overseas, which it is also known as 'off-shoring', where outsourcing might be in the form of manufacturing or service providing such as call centers and customer care (Milberg \& Winkler, 2013).

Outsourcing promotes a culture of interdependence between business leaders and their respective businesses on a global, regional and domestic scale. Outsourcers are dependent on 
outsourced partners for having access to labor, resources and for supplying their products to consumers. Their outsourced partners are also dependent on them for business. For example, the retail sector, which supplies finished products such as coffee, clothing, and footwear, is dependent on the manufacturing sector, which manufactures these products. The manufacturing sector is dependent on the suppliers of raw material such as the coffee bean growers, the cotton growers and the latex harvesters. All three of these sectors are dependent on the logistics companies, which are transporting, storing and distributing the materials between the sectors, and also making the outsourcer's finished products available to consumers. It can be said that the main participants in outsourcing are the laborers who are engaging in all sectors and that their interests are being protected by the notion of CSR. For example, the cotton growers and the latex harvesters would like to be able to trade their produce fairly in order to maintain a sustainable business. A retailer's CSR would be that they ought to be trading with the suppliers of raw materials fairly.

The interdependence between businesses is conventionally bridged by a minimal legal requirement, which is a bilateral outsourcing agreement between the outsourcer and the outsourced partner (Willcocks, Cullen \& Craig, 2011). It is also considered best practice that a code of conduct is incorporated into the agreement (Willcocks et al., 2011), which protects the interests of third parties and protects the interests of the outsourced partner's employees. A code of conduct codifies CSR values because this document acknowledges stakeholders' interests such as socio-economic rights. These values will generally manifest in their pragmatic form focusing on the socio-economic needs of employees such as employees being paid fair wages, having resting periods, and being provided with a safe working environment. It is the outsourcer's social responsibility to ensure the implementation of these codes of conduct and that it is the outsourced partner's governance to abide by them. Here, CSR is not entirely shared between two parties because one implements and the other abides.

In some instances, both parties overlook CSR. As a result, the interests of laborers are not protected. The media has uncovered instances whereby there is a deficiency in implementing CSR practices. This chapter utilizes the 2010 suicide incidents at Foxconn's factory in China (The Guardian, 2013, August 02) and the 2013 Rana Plaza's collapse in Bangladesh (The Guardian, 2013, October 24) to demonstrate this deficiency, which is the result of outsourcing's minimal legal requirement.

Even where CSR values - such as remunerating employees fairly and providing them with a safe working environment - are incorporated into the bilateral contractual arrangement, in the two instances (Apple, 2014; Primark, 2011) the tragedies indicated that their enforcement is questionable. The two examples show that there are instances, which can give rise to the disregard for CSR. Through an aspect of social philosophy, this chapter explores the instances where the total disregard for CSR practices can happen, albeit that these practices were agreed by the outsourcing parties. It is found that a bilateral agreement cannot deter the parties from 'legitimately forgetting' (Gilbert, 1992) about CSR practices. Furthermore, the outsourced partner's employees who might want to enforce their third parties rights would have had encountered many legal hurdles. It is shown in Doe v. WalMart Stores, Inc. (2009) in the Appeal Court that the outsourced partner's employees' attempts for seeking redress from the outsourcer were found to be of little avail because they had been unsuccessful (Doe v. Wal-Mart Stores, Inc. (2009), p. 8619).

In the current economic climate, it is understandable that businesses favor outsourcing because of it being more cost effective. Outsourcers have opted for the lessening of their responsibility and the reduction of cost in the interest of keeping businesses afloat. However, a bilateral agreement, which governs most outsourcing activities, does not guarantee a shared responsibility between the outsourcer and the outsourced partner for the protection of labor. This is because this agreement does not deter the overlooking or forgetting of CSR by both parties.

It is advanced in this chapter that instances like the legitimate forgetting of CSR could be prevented if outsourcing could be viewed as a joint activity shared amongst all of its participants. They include the outsourcer, the outsourced partner, the supplier of raw materials and the members of logistics. Business leaders of each of these participants ought to empower themselves with CSR 
values promoting the practice of CSR - not as a sole responsibility for one business alone, or for only one employer; but - as a shared responsibility. For example, a shared responsibility is making sure that finished products are made available to consumer without damaging the working environment of all supply chains. The act of acting together (Gilbert, 2008) through a joint activity is the foundation for 'Ethical Outsourcing'. Achieving the practice of ethical outsourcing is not just something that legislators could do; but it is also very much dependent on organizations shaping their contractual obligations through their leadership.

The incentives for business leaders to embrace ethical outsourcing are as follows. First, the pool of resources and knowledge is shared between all participants. Second, the maintaining of the workforce's wellbeing is shared responsibility amongst all participants. Third, the reduction of maintenance costs resulting from the sharing of resources and responsibility. Fourth, a multi-lateral agreement promotes participants engaging in joint problem solving. Stakeholders who are prima facie parties to the agreement have the knowledge to solve problems (Levine, 2009), such as Just-In-Time delivery and product revitalization, without straining the workforce. Hence, engaging with stakeholders reduces cost and promotes the 'ethical trading brand'. Fifth, the practicing of CSR from all participants reduces the frequency of tragedies such as the 2010 Foxconn Suicides and the 2013 Rana Plaza Collapse. The prevention of tragedies protects the outsourcer's brand from reputation damage and also promotes consumer appeal.

In preparation for the 2016 Olympics and the 2022 World Cup, outsourcing will play a huge role in areas such as building construction, transportation and the production of merchandise. A change in the outsourcing participants' leadership could prevent incidences such as the deaths of migrant construction workers and the potential setting up of sweatshops in contravention of every rule in the code of conduct.

\section{BACKGROUND}

\section{Literature Review}

\section{Joint Actions}

A joint action is when two or more parties agreed to undertake a task together (Gilbert, 1992). Outsourcing matches this description because it requires an agreement with at least two or more parties. The legal requirement for outsourcing is two parties - the outsourcer and the outsourced partner. However, outsourcing is a task involving numerous parties such as the employees of the outsourced partners, the suppliers of raw materials and semi-finished products, as well as the logistics. Therefore, the social requirement for outsourcing is favored because it includes more parties than the legal requirement. Nevertheless, any tasks, which involved a joint action, will require a 'meshing of plans' (Bratman, 1999).

\section{The Meshing of Plans}

Parties who are involved in a joint action are also involved in the meshing of plans (Bratman, 1999). The meshing of plans is the planning and coordinating of individuals making a joint action workable (Bratman, 1999). A bilateral contract is a symbol of a meshing of plans whereby the parties' agreed terms and conditions are being performed through planning and coordinating. For example, the outsourcer plans the tasks and targets and the outsourced partner would coordinate and deliver the goods. Once the goods are delivered, the outsourcer would then honor the contract by way of a payment. A bilateral contract between only two parties would entail fragmented contractual obligations between them. For example, the outsourcer has a bilateral contract with the outsourced partner. The outsourced partner would have a separate bilateral contract with the suppliers, and another separate agreement with the logistics companies. In each of these transactions, the parties might have or might not have incorporated CSR practices. The meshing of plans is upheld through the mutual assurances of the parties (Bratman, 1999). Therefore, it is viewed that a legal document such 
as a bilateral contract is superfluous when it comes to practicing CSR. For example, in a given situation where CSR practices are mutually assured by the two parties, their contractual obligations are being discharged. However, in a given situation where CSR practices are not mutually assured by the parties, these practices are often subjected to the process of legitimate forgetting (Gilbert, 1992). In the instances where the legitimate forgetting of CSR practices occurs, the contractual agreement provides little to no protection for remedies or consequences. Therefore, the CSR values being codified in the codes of conduct have little binding effect.

\section{Legitimate Forgetting}

Parties in agreement might decide to legitimately forget (Gilbert, 1992) about their joint activity. Outsourcing can be categorized as a joint activity whereby the outsourcer and the outsourced partner have agreed to work together under certain terms and condition. In some instances, the terms and conditions can be unilaterally violated by one of the parties (Gilbert, 1992) and this may then initiate a legitimate forgetting. For example, the outsourced partner violates the CSR practices, which are incorporated into the agreement and as a result of this; the outsourced partner's employees are being exploited. In this given instance, the outsourcer can choose either to uphold the codes by subjecting the outsourced partner to rehabilitation; or to legitimately forget about the existence of these practices. If the outsourcer chooses the former, the CSR practices are upheld and its purpose is met. If the outsourcer chooses the latter, the CSR practices are legitimately forgotten because the outsourced partner is not observing them and the outsourcer is not implementing them.

The legitimate forgetting of CSR practices is beneficial for both outsourcing parties because it entails no incurred consequences. The outcome of Does v. Wal-Mart Stores, Inc. (2009) in the Appeal Court absolves the outsourcer from the responsibility to care for the well-being of the outsourced partner's employees (Doe v. Wal-Mart Stores, Inc. (2009), p. 8619). Further to that case, the outsourced partners having resided in jurisdictions with weak labor laws were also not held accountable for their wrongdoings. The employees of Wal-Mart's outsourced partner were based in Indonesia, Bangladesh, Swaziland, China, and Nicaragua. As the result of that court's finding in Does v. Wal-Mart (2009), the outsourced partner's employees who have suffered because of the nonimplementation of CSR practices had no redress.

This chapter views that the legitimate forgetting of CSR practices is an issue which has resulted in the instances such as the 2010 suicides and the 2013 building collapse. These instances had happened on a macro scale. One must also be aware that there are incidences happening on a micro scale and that they are mostly being undetected by the media and also by international governing bodies such as the International Labor Organization, an international body that oversees the protection of laborers' well being. Therefore, it is important to address these issues.

\section{The Act of Acting Together and the Joint Commitment}

An approach to limit the legitimate forgetting of CSR practices amongst outsourcing partners is to integrate the nexus of the fragmented contracts through the concept of an act of acting together (Gilbert, 2008). The process of legitimate forgetting is minimized when each participant is jointly committed (Gilbert, 2008) in performing a task with the other participants. A joint commitment is most vulnerable between two participants because there is a high tendency that both can decide to mutually forget about the task by replacing it with a new task. In outsourcing, an outsourcer and an outsourced partner could forget about engaging in what is written in their bilateral contract and subsequently they could agree to a new joint activity engaging in irresponsible outsourcing. A multilateral contract, in contrast, introduces several stakeholders on board such as the suppliers of raw materials, members of logistics and labor representatives.

In a multi-lateral contract of this kind, each participant has locus standi and each can equally demand the performance of the contact's terms and conditions. Thus a code of conduct, which is incorporation into the contract, is unlikely to be forgotten because a participant would invoke an interpersonal demand for the performance of obligation against a fellow participant violator (Ang, 2012). The incentives for business leaders to include stakeholders as parties to their outsourcing 
agreement are as follows. First, the leaders can access the wealth of knowledge that stakeholders have in the light of sustainable solutions to alleviate the pressure on the workforce. Second, the joint solution finding between business leaders and stakeholders can create a more effective program for production, planning and audit. Third, trust between the outsourcer, manufacturers and suppliers is strengthened and a long-term relationship is maintained because the outsourcer is less likely to replace one outsourced partner with another. Fourth, the reports on labor and production by both the outsourcer and its stakeholders are being made more transparent and transparency of this kind builds consumer trust and appeal. Fifth, all participants are in an act of acting together by virtue of a multilateral contract, which promotes ethical outsourcing and minimizes CSR forgetting.

\section{Leadership}

Leadership is the crux for effective ethical outsourcing. Business leaders can empower themselves by being willing to participate in a multi-lateral agreements with the key participants in outsourcing. The sharing of CSR practices between the participants can invoke a transformational leadership style, which creates intellectual stimulation, individualized consideration, individualized influenced attribution and individualized influence behavior (Ismail, Mohamed, Sulaiman, \& Yusuf, 2011). The knowledge sharing and joint-solution finding between participants could aid leaders shaping the corporate governance of their businesses. For example, the companies involved in Global Business Coalition projects are advancing better education and medical advances fighting against Malaria, Tuberculosis and Aids. Not only have these projects benefited stakeholders; but the employees of the participating companies would have also benefited through boosting of their morale. Thus, the empowerment of leaders traverses into empowering their own organization creating an organizational commitment to CSR practices. The interests of stakeholders (i.e. laborers) are interwoven into the organizational commitment and therefore their interests can boost the CSR-participant's labor morale. These three features - organizational commitment, transformational leadership and empowerment are interrelated and interconnected (Ismail et al., 2011). Therefore, as one of the three features is adopted, the rest will follow. A multi-lateral contract written in the light of ethical outsourcing gives legal strength to this form of leadership.

\section{MAIN FOCUS OF THE CHAPTER}

This chapter's main focus aims to demonstrate that the fragmented obligations under bilateral outsourcing contracts do not guarantee parties' CSR practices. The 2010 Suicides at Foxconn Factory in China and the 2013 Rana Plaza Collapse in Bangladesh are two examples utilized. They show the forgetting of CSR values, which are incorporated into the outsourcer's practices. These practices had not been implemented by their outsourced partners. The two examples demonstrate the instances where the CSR practices are overlooked by the contractual parties and they have resulted in grave consequences. The heart of this problem is believed to be in the minimal legal requirement to outsource.

This chapter provides a critical analysis of outsourcing's legal requirement, which goes contrary to the social aspect of outsourcing. This social aspect is believed to be an act of acting together from all of outsourcing's participants (Gilbert, 2008). The current method of outsourcing enables the parties to legitimately forget (Gilbert, 1992) about their CSR obligations towards their employees or other laborers (Low, Idowu \& Ang, 2014). Thus, in the instance where CSR practices are overlooked, outsourcing's current legal requirements will not provide an efficacious solution.

This chapter therefore advances an approach whereby it is believed that the incorporation of the idea of outsourcing being an act of acting together into contracts will transform the practice of CSR. Under a bilateral agreement, the implementation of CSR practices is entirely the onus of the outsourcer. The current idea of CSR is somewhat confined to an isolated mission for a business, which it undertakes voluntarily. Voluntarism does not empower a business because a business cannot shape the behavior of its CSR violating partner. The proposed idea of CSR will transform this current idea into one that is of a shared responsibility between every participant in outsourcing. Thus, it transforms outsourcing's legal requirement from a bilateral agreement into a multilateral one. This transformation is heavily dependent on business leaders and their leadership. Leaders must empower 
themselves to share their responsibility for CSR practices with outsourcing's key participants. Thus, the concept of CSR being a shared responsibility begins with an act of acting together amongst the participants and this is the foundation for ethical outsourcing.

\section{The 2010 Suicides at Foxconn Factories}

In 2010, 18 young employees attempted suicide at Foxconn's factory in China, resulting in 14 deaths (The Guardian, 2013, August 02). Foxconn is a Taiwanese multinational corporation that manufactures gadgets for its outsourcers such as Apple, Dell, Hewitt-Packard and IBM (Money Watch, 2013, August 07). At present, none of Foxconn's managers or its directors has been held responsible for the deaths.

It was speculated by the media that the attempted suicides, which had happened very closely together, were caused by the intense pressure placed on Foxconn's employees to produce mass quantity of products in a short space of time (The Guardian, 2013, August 02).Not only were its employees put under pressure to achieve production targets; they were subjected to a military-style working environment (BBC News, 2010, May 28).Twelve-hour shifts meant that employees had little recreational or resting time. Employees also had no opportunity to have conversations with colleagues and therefore they had no opportunity to make friends. Some of the employees had even sacrificed their resting and meal times by working late in order meet production targets. The employees' achievements were not appreciated by the management because the goals were subsequently replaced by increased new goals (Money Watch, 2013, August 07). There was no evidence to show that they were given appraisals or rewards for the targets met. On the contrary, more pressure is added in terms of increased production targets and goals.

The combination of the production's targets and the military-style working environment had resulted in some of the young employees attempting to take their lives by jumping out of their dormitory windows. An investigation has revealed several core problems underpinning Foxconn's handling of the suicide incidents. First, the management's initial response to the first series of incidents was to force all remaining employees into signing a pledge that they 'will not attempt suicide' (Daily Mail Reporter, 2011, May 01). Second, the management's removed the 100,000 Yuan compensation scheme to deter further employees from attempting suicide (BBC News, 2010, May 28). The purpose of this scheme was to compensate the employee's family upon his or her death at work. And finally third, the management replaced the 100,000 Yuan compensation with an award of a 'minimum in damages' upon a worker's death at work (Daily Mail Reporter, 201, May 01).

The management's reaction in preventing employees from taking their lives only highlights the modus operandi of those who had attempted suicide. Many of these young workers took up employment at Foxconn's factory in the hope of providing a decent life for their families. The poor working conditions and the low pay, which these employees are receiving, could not divert them away from the quick fix route into satisfying their families' financial needs. The 100,000 Yuan compensation paid to an employee's family for his or her death at work seems a lucrative (but, an irreversible) venture. Although one might argue that Foxconn had met what seemed like the basic human rights needs of an employee because a place of work and a comfortable place of dwelling had been provided; arguably, those facilities were simply not enough. The series of suicide attempts are indications that the socio-economic well-being of laborers ought to be taken into consideration and they cannot be neglected.

The 2010 suicides have opened a dialogue between Foxconn and Apple (Sydney Morning Herald, 2012, December 27). Apple executives have been putting pressure on Foxconn to make labor reforms in its factory. The change in the working environment has been very slow; but any improvement is a small step towards enhancing the quality of at least 400,000 employees' working lives (Sydney Morning Herald, 2012, December 27). The dialogue has resulted in Foxconn being more transparent about its operations and management. In 2012, the labor inspector reported that Foxconn had demonstrated various failings which include the following: it had failed to stop illegal overtime, it had failed to keep student interns from nightshifts, and that it had also failed to implement 
sufficient safety policies (Sydney Morning Herald, 2012, December 27). Interestingly, the labor inspector had not solely blamed Foxconn for these failings. It was found that the outsourcer (in this case, it is Apple) was also to blame for being jointly responsible for those failings.

In essence, the crucial dialogue between Foxconn and Apple has resulted in a sharing of CSR between Apple and Foxconn. Therefore, the practice of CSR is not Foxconn's burden alone; rather it is the shared responsibility between Foxconn and its outsourcers. It is argued, however, that opening a dialogue between an outsourcer and an outsourced partner is not a satisfactory or sustainable solution because one might find it difficult to measure an outsourced partner's commitment to practice CSR. It is one thing to express awareness of CSR practices and it is quite another thing when one has practiced CSR. The former requires no commitment, but commitment plays a role in the latter. Although a dialogue might have ensured the sharing of CSR responsibilities, it does not determine that both parties' are indeed sharing - or that they are even committed to - CSR practices. A report in May 2013 has revealed this concern because it is reported that attempted suicides by Foxconn employees are still occurring at its factory (Patently Apple, 2013, May 18).

\section{The 2013 Rana Plaza Collapse}

On $24^{\text {th }}$ April 2013, a garment factory building, the Rana Plaza in Bangladesh, collapsed killing 1,129 workers. This tragedy has affected many people who were injured at the scene and who are still suffering from their injuries such as amputations, paralysis, sharp pains in their body and psychological trauma. The families of the injured and the dead are also suffering emotionally and financially (The Guardian, 2013, October 24).Pressure groups, such as Oxfam, were quick to highlight the hidden cost of cheap clothes being achieved through the use of sub-contracts (Oxfam, 2013, April 26). Although outsourcers are accessing cheap labor and resources through the web of sub-contracts, laborers are paying with their lives, which result in long-term social problems.

In the case of the Rana Plaza, cost cutting was made on both labor and resources. The Plaza was only meant to stand five stories high; but three stories were illegally added onto the original building. As the new stories were added, more factory machinery and laborers occupied the spaces. It was reported that the collapse was the result of the various poor features in the building and are as follows - 'poor workmanship, overloaded upper stories, low-strength materials [used], an abnormal column layout and [a] lack of load-path continuity' (Engineering News-Record, 2013, July 05). In essence, the material used for the construction of the plaza and its spaces were exploited for the increased number of machinery, laborers and rate of production.

The laborers who had worked at the plaza were forced to work long hours and were also kept in hazardous working environments. As a result, their socio-economic rights were violated. It is argued that had it not been for the collapse; these violations would have been carried on without being detected by either the Bangladeshi authorities or the independent auditors. The non-detection of these violations was the result of both the outsourcing parties' neglect for CSR practices. The outsourcing partner had not implemented the code of conduct and the outsourced partner had not observed the code. Furthermore, in the web of sub-contracts, it is impossible to accurately hold any of the participants (such as the engineers who built the Rana building or the complicit sub-contracted manufacturers) responsible for the initial socio-economic violations. So far, the only persons being investigated are the owners of the building and the owners of the factories (BBC News, 2013, April 25). CSR practices seemed to have disappeared. Furthermore, the holding of individuals responsible for CSR breaches seems very difficult.

Remarkably, Primark, one of the many outsourcers having ties with the manufacturers in the plaza, was the only one who has offered to compensate the victims (The Guardian, 2013, October 24). Primark voluntarily extends its CSR to the victims, which no other multinational corporation such as Matalan and Bonmarche were prepared to do. Although Primark's gesture might be a way of promoting its 'ethical-trader' image, it has nevertheless shown that the voluntarism of CSR is the crucial factor to the unilateral practice of CSR. 
The Rana Plaza tragedy highlights two points - (1) outsourcing and its further sub-contracting entails a fragmented cluster of obligations between the various parties. This leads to some instances of non-implementation of CSR practices because both parties would choose not to and perhaps that leads to the non-existence of CSR. (2) The voluntarism of CSR plays a very important role in making amends. Voluntarism also promotes CSR practices. Outsourcing partners being committed to CSR practices is the ideal approach to CSR promotion. However, CSR practices cannot be guaranteed in the absence of voluntarism. Furthermore, Primark's voluntary gesture in making amends is retrospective. Therefore, voluntarism in this form is an unsatisfactory solution to the practice of CSR.

\section{The Forgetting of CSR results in an Enforcement Vacuum, which can be bridged}

The two examples have shown that the violated laborers' socio-economic rights were the result the outsourcing partners' neglect for CSR. Despite the incorporation of corporate codes of conduct, it has not prevented the instances where laborers' socio-economic rights are violated. Therefore, there is what is believed to be an enforcement vacuum. Although the corporate codes of conduct are important and the protection of socio-economic rights and well-being of laborers have been acknowledged; one might encounter several legal difficulties when enforcing them.

First, the successful enforcing of these codes largely depends on the host state's domestic laws. Outsourcers conducting off-shoring might find it useful to circumvent strict labor laws by selecting business partners residing in host states which favored Foreign Direct Investments (FDIs) over labor protection. In the case of Foxconn, the fact that none of Foxconn's directors were prosecuted for the suicides sends a message that its host state has no political interest in holding them accountable. In the case of Rana Plaza, the fact of the long term exploitation of labor and resources, which had not been detected before the collapse, sends a message that its host state either had not implemented; or that it had not given the appropriate body the resources to implement its labor laws or its health and safety laws. Therefore, even if the codes of conduct were incorporated into the outsourcing contract, they might not be enforceable in some host states.

Second, in addition to the choice of favorable host states, an outsourcer might not be held accountable for the exploitation of labor and resources, which were conducted by its overseas outsourced partner for the following two reasons. (i) The domestic laws where the outsourcer resides do not have extraterritorial effect over, and therefore cannot protect the interest of, its overseas outsourced partner's employees (Wal-Mart Stores, Inc., 2007) (in the Court of First Instance).(ii) International law does not recognize socio-economic rights violations because they are not categorized under international crimes. Therefore, they do not come under the governance of international law (Wal-Mart Stores, Inc., 2007) (in the Court of First Instance). Thus, these are the reasons for suggesting that the outsourcers and their outsourced partners might not be held accountable for breaching the incorporated codes. In essence, the laborers cannot seek redress under either the domestic law governing the outsourcer's conductor under international law governing both the outsourcer and the outsourced partner's conduct.

Third, although the laborers have third parties rights under the bilateral outsourcing contract, the invoking of these rights is an unsatisfactory route in seeking redress. This is because of the doctrine of privity in contract law. As mentioned, the main parties to an outsourcing contract are the outsourcer and the outsourced partner. The laborers gain third parties interests by virtue of the incorporation of the codes of conduct. Under an outsourcing contract, it is the promisor of the codes who is under the obligation to uphold them (Wal-Mart Stores Inc., 2009) (in the Appeal Court). The promisor is the party who promises to implement these codes. This is therefore the duty of the employer (Wal-Mart Stores Inc., 2009) (in the Appeal Court). An overseas outsourced partner residing in a host state, which favors FDIs over labor protection, might have breached these codes, and thus, the promisor-outsourced partner has broken the promise to its promisee-outsourcer, about protecting its employees. This in turn gives the third parties, who are the outsourced partner's employees, the opportunity to sue the promisor (the outsourced partner) for redress. The chances of success are very slim because some host states might not protect third parties rights under their 
domestic laws. Here, the outsourcer's role of enforcing CSR in the light of the codes under this kind of contract is hollow (Wal-Mart Stores Inc., 2009) (in the Appeal Court).It is because the incorporation of the codes, which does not guarantee the parties acting on them. Not only does the promisee-outsourcer have no obligation to uphold the promise, it also does not see the benefits of implementation or enforcement (Wal-Mart Stores Inc., 2009) (in the Appeal Court).

Fourth, it can be seen in this discussion that bilateral contractual agreements have resulted in unenforceable CSR obligations because these obligations are being fragmented between several different sub-contracts and parties. A bilateral contract binds only two parties. The further subcontracting of tasks onto the chain of production entailed the creation of even more sets of obligations under several contracts. The fragmented obligations of this kind decrease the governance of outsourcing abuse and also they decrease the practice of CSR.

Fifth, the enforcement of the codes between the outsourcer and outsourced partner might be seen to be unfavorable for both parties because it might lead to cost inefficiency. Auditing practices in factories might have increased transparency in production; however the implementation of the auditor's recommendation might be costly for the outsourcer. An auditor's recommendation might include one of the following (Wal-Mart Stores, Inc., 2007) (in the Court of First Instance); (1) an outsourced partner who has been shown to have violated the codes might have to undergo rehabilitation, or (2) an outsourcer might have to sever business ties with an outsourced partner who has been shown to be a persistent violator of the codes. Both of these recommendations incur cost and inconvenience. Therefore, they are unfavorable to the outsourcer's business. As it is noted in the two examples, the cost of either an outsourced partner's rehabilitation or the severance of business with them might be the reason why the big apparel retailers allowed the appalling practices to continue at the Rana Plaza. Interestingly, Foxconn, despite being a persistent violator of its codes of conduct, have not harmed its business ties with its major outsourcers. Its violation of the codes entails no financial or business consequence.

These are the five reasons for the bilateral contract's enforcement vacuum which legitimizes the partners forgetting about their CSR practices should they choose to. Nevertheless, this enforcement vacuum can be bridged by the partners. If the two partners are committed to CSR practices, then the incorporated code of conduct into their contract is fulfilled and is subsequently discharged. The enforcement vacuum can also be bridged by the outsourcer's arrangement of independent audits subjecting the outsourced partner to rehabilitation or spot checks to ensure that the codes are not violated. However, it seems that the bridging of this bilateral contract's enforcement vacuum is heavily onerous on the outsourcer. The audits and the subsequent rehabilitation as when there is a breach of the codes require resources and thus they incur cost. As it is seen in the Foxconn example, the outsourcer's commitment to enforce the codes could embed a small change in the behavior of a persistent violator. This kind of unilateral effort being put into practice might not be economically viable for smaller outsourcing businesses. CSR practices are therefore costly for a committed business (such as the Apple and Primark) acting alone.

\section{Forgetting CSR and its Appeal}

It can be seen from the discussion above that keeping the commitment to honor third parties rights is mainly an outsourcer's responsibility. In a given situation where both partners are committed to CSR practices, third parties rights are discharged. However, in a given situation where both parties choose to forget about CSR practices, the legal loopholes in the regulation of outsourcing found in international, domestic and transnational laws might not aid third parties in enforcing their rights.

It is seen in Foxconn's example that the persistent violator of third parties rights was being lethargic to its outsourcer's requests in improving its employee's well-being. It is seen in the Rana Plaza example where there was the non-implementation of third parties rights by both the outsourcer and the outsourced partner. In both these instances, the incorporated CSR codes were somehow being forgotten. Thus, the incorporation of these codes into the bilateral agreements has only boosted the partners' image of being 'ethical traders;' but has not guaranteed the practice of CSR. 
It is because the codes of conduct could be forgotten (Gilbert, 1992). In order to understand the forgetting of codes by the outsourcing partners, one would examine the stages of creating an agreement by the partners undertaking the activity. A joint activity is created when two parties come to an agreement to undertake a task. This joint activity results in a range of rights and responsibilities that are neither legal nor moral; rather they are associational (Gilbert, 1992). Associational rights and responsibilities are maintained through the mutual assurances of both parties (Bratman, 1999). Similar to an outsourcing transaction, the outsourcer and the outsourced partner agreed inter alia to protect the well-being of their third parties. Their mutual assurances in maintaining their agreement are being molded and are shaped in accordance with their activities (Bratman, 1999).

There is a possibility that the initial joint activity could be dissolved and a new joint activity could replace it (Gilbert, 1992). The dissolution of the initial joint activity can result from either one of two instances. First, an initial joint activity could be dissolved when one party persistently violates the agreement's terms and conditions. For instance, if an outsourced partner persistently fails to observe and implement the incorporated codes, this partner would become the unilateral violator. The other party is left with no choice but to forget the whole agreement altogether (Gilbert, 1992). Second, both parties could agree to forget about the specify terms and conditions altogether. For instance, the outsourcer and the outsourced partner could both agree to forget about third parties right when undertaking business. In both instances, the initial agreement would be legitimately forgotten and replaced by the parties with a new joint activity. The forgetting is legitimate because no consequence is incurred from the process of dissolution (Low et al., 2014). The outsourced partner does not suffer any penalties and the outsourcer does not suffer any incurred cost (Low et al., 2014). CSR practices, albeit being acknowledged by its outsourcing partners are forgotten because none of the partners are implementing those practices.

This legitimate forgetting enables both parties to create a new joint activity, which does not reflect their outsourcing contract because this new joint activity would be comprised of all the terms and conditions except the ones protecting third parties rights. In essence, the contractual obligations under the outsourcing agreement would not reflect the new associational obligations, which have overridden those CSR practices. An outsourcer could see the appeal of CSR forgetting because an outsourcer would alleviate itself from the burden of auditing and rehabilitating the outsourced partner. This seems to be the unfortunate product of a bilateral contractual agreement whereby an outsourcer is solely responsible for the assurance of the outsourced partner's CSR practices. This responsibility seems to be too onerous for an outsourcer especially when working with a persistent CSR violator.

\section{Bilateral Contracts seem to facilitate Irresponsible Outsourcing}

Outsourcing partners who are not committed to CSR practices are more likely to legitimately forget about third parties rights. Bilateral contracts are based on a faulty foundation putting too much onus on an outsourcer ensuring that CSR practices are being adhered to. This incurs cost on the outsourcer. Furthermore, a bilateral contract's enforcement vacuum gives outsourcers the temptation to forget about CSR practices when working with a persistent violator. To minimize outsourcing partners giving into this temptation, one has to highlight where the problem lies.

The problem lies in the minimal legal requirement to outsource which only includes the outsourcer and the outsourced partner. Both the parties' associational obligations are predominately similar because they have an interest in minimizing cost. Thus, whatever is included in their bilateral contract which does not match their interests will eventually be ignored because a persistent violator's agenda will most likely overpowered the agreement. Indeed, in this manner, it is argued that the bilateral contract is insufficient to capture the true act of outsourcing.

An associational agreement could withstand the process of legitimate forgetting if all participants are included in a joint activity (Ang, 2012). The embracing of this idea would turn a bilateral contract into a multilateral one because the key participants would include the outsourcing partners and particular stakeholders such as members of logistics, the suppliers of raw materials and labor representatives. The essence of an act of acting together is inclusive of stakeholders' interests 
and therefore requires a change in the leadership of the outsourcing partners, especially the outsourcer.

\section{A Change in Leadership embracing an Act of Acting Together}

As mentioned before, an act of acting together involves participants in a joint activity. Outsourcing can be said to be an example of a joint activity because it involves numerous participants. Those include the outsourcer, the outsourced partner, the other suppliers, auditors, logistics and the employees. Indeed, the nonparticipation of one of the participants would result in the collapse of the joint activity. For example, the nonparticipation of the employees would render the production of goods and services impossible, and that would also be the case if there were a nonparticipation of suppliers. Therefore, a joint activity can only be achieved when all participants have acted on their joint commitment (Gilbert, 2008). It can be argued that the participants' joint commitment keeps the joint activity from undergoing the process of legitimate forgetting (Ang, 2012).

In bilateral contracts, there is a high possibility that the joint commitment between two parties in minimizing cost has enabled them to replace the other participants of outsourcing. Manufacturers who refuse to lower their cost of production are more likely to be replaced by cheaper ones. Thus, the outsourcing parties that are not committed to CSR practices are picking participants who are most likely not to observe CSR practices. The process of legitimate forgetting is being used to sever business relationships with others who are outside the bilateral contract and it is also being used to alter contractual terms and conditions. The incorporation of all key participants could minimize the process of legitimate forgetting of CSR practices. Thus, the joint activity would involve the joint commitment from all. The legal status of every participant would be equal because every participant would be a party to the contract. There would be no need for recourse in (the problematic task of) invoking third parties rights. The content of the multilateral agreement would include the tasks and the interests of all. Negotiation of the terms and conditions is crucial because the practice of CSR by all must be balanced alongside business models such as the Just-In-Time (JIT) system.

The joint commitment from every participant would enable every participant to invoke an interpersonal demand of the contract's terms and condition from others (Gilbert, 2008). For example, if an outsourcer sets a launch date, which places too much pressure on the chain of production, every affected participant could invoke a direct interpersonal demand against the outsourcer, making it observe the terms and conditions of the contract. This kind of interpersonal demand would ensure that the outsourcer arranges a launch date that fits into the plans of all. A similar pressure is also placed on the outsourced partner who may have tendencies towards being a persistent violator. If an outsourced partner acted in violation of the terms and conditions; the labor representative, the independent auditor and the outsourcer would have a stronger say on the violator's system of operation by invoking an interpersonal demand against the violator to stop violating or face the likely consequence of severed business ties. Facing real consequences from being a persistent violator can deter any participant from contradicting the terms and conditions of the multilateral agreement.

Apart from the invoking of interpersonal demands by participants against others, a multilateral agreement can also initiate dialogues between all the participants. These dialogues can open up opportunities of transparency, knowledge sharing and joint problem-solving amongst the participants (Levine, 2009). The dialogues between participants would reinforce the act of acting together and the sharing of CSR practices. Empowerment would come from the knowledge sharing and joint problem-solving between the participants. Thus, the outsourcer and the outsourced partner would no longer have the upper hand of pushing CSR practices away. Rather, all participants will be taking ownership over and sharing each other's CSR practices.

Outsourcing's shift from being a bilateral agreement into a multilateral one heavily relies on leadership. Leadership is the crux for effective ethical outsourcing. Business leaders can empower themselves by being willing to participate in a multi-lateral agreement with the key participants in outsourcing. The sharing of CSR practices between the participants can invoke a transformational leadership style, which creates intellectual stimulation, individualized consideration, individualized 
influence attribution and individualized influence behavior (Ismail et al., 2011). The knowledge sharing and joint-solution finding between participants could aid leaders shaping the corporate governance of their businesses. For example, the companies involved in projects, which are organized by the Global Business Coalition in New York, USA, are advancing better education and medical advances fighting against Malaria, Tuberculosis and Aids. Not only do these projects have benefits for stakeholders; the employees of the participating companies would have also benefited through boosting of their morale. Thus, the empowerment of leaders traverses into empowering their own organization creating an organizational commitment to CSR practices. The interests of stakeholders (i.e. laborers) are interwoven into the organizational commitment and therefore their interests can boost the CSR-participant's labor morale. These three features - organizational commitment, transformational leadership and empowerment - are interrelated and interconnected (Ismail et al., 2011). Therefore, as one of the three features is adopted, the rest will follow. A multi-lateral contract written in the light of ethical outsourcing gives legal strength to this form of leadership.

\section{Recommendation: Empowering Organizations through the Act of Acting Together}

The discussion in this chapter has explored the enforcement vacuum in international law, domestic law and transnational law in ensuring outsourcing partners' commitment to CSR practices. This vacuum is depicted in the examples of Foxconn and the Rana building collapse. In a given instance where CSR practices are not met, third parties rights are not easily invoked in the courts. One of the underlying reasons why bilateral outsourcing contracts are difficult to enforce is because of the process of legitimate forgetting, which enables the replacing of contractual terms and condition with new associational agreements by non-CSR committed outsourcing partners.

The discussion has also demonstrated that bilateral contracts have resulted in fragmented obligations amongst those participants in outsourcing. This kind of contract also places onus on the outsourcer committing to CSR practices. Outsourcers are burdened with conducting audits and rehabilitation that can be costly if faced with a persistent CSR violator. Outsourcers who are not committed to CSR practices are able to replace existing partners with cheaper ones in the interest of reducing their costs of production. Suppliers could also be replaced by cheaper ones. As a result, the practice of CSR is being pushed away by those kinds of outsourcer and the outsourced partner leaving the other participants baring the burden through exploiting and abusing labor and resources. For example, the manufacturing sector is constantly driving down the prices of raw materials to keep cost low.

Outsourcers who are committed to CSR practices are acting on voluntarism. The example of Primark's reaction towards the Rana Building collapse demonstrates the powers of voluntarism in practicing CSR and of protecting corporate reputation. Although voluntarism in practicing CSR is an admirable act, corporations are placed with a heavy burden. This is because of the lack of a shared responsibility amongst participants. It is argued in this chapter that the pushing away of CSR between business partners has made it costly and burdensome for the ones who are actually engaged in practicing them.

For example, if Apple champions better working conditions at Foxconn's factory, it would require Apple investing heavily on audits and the mechanisms to make sure that Foxconn complies with those recommendations. The cost of these tasks might fall onto Apple's customers. Foxconn's other outsource partners, having been passive about its working conditions, would have eventually benefited from Apple's CSR project. Thus, the other outsourcer's would have gained a competitive edge over Apple on two fronts. First, they would be using Apple's ethical methods of production without internalizing the cost. Second, Apple's products would become more expensive than their own. This outcome would be unfavorable to Apple if it decides to commission a CSR project.

With the competitive price reduction generating consumer appeal, the undertaking of CSR by a corporation acting alone is impractical. Thus, business leaders in all sectors of outsourcing have to empower themselves into shifting outsourcing agreements from a bilateral into a multilateral 
agreement. A sharing of CSR responsibility is empowering because each participant would take ownership over the task. Each participant would have an agreeable set of rights and responsibilities that they must perform for the task to be successfully achieved. The sole burden on the outsourcer is automatically alleviated, minimizing the temptation to circumvent responsibility. The inclusion of all participants would ensure that each participant pulls their weight in upholding both tasks of outsourcing and also CSR practices.

A multilateral contract empowers the suppliers, laborers and people in logistics in the invoking of interpersonal demands against the outsourced partner and the outsourcer. A multilateral contract is also a platform for knowledge sharing, joint solution-finding and the sharing of risks amongst all participants through which leader scan empower their organizations through engaging in intellectual stimulation and individualized influence behavior (Ismail et al., 2011). A shared responsibility would have an influence over the leaders' corporate governance of their organizations embedding an organizational commitment to CSR practices. Outsourcers and outsourced partners ought to listen to the other participants and alter their corporate governance into a flexible model. Thus, the Just-In-Time delivery system and short-period mass production have to give way to more innovative and sustainable methods.

A multilateral contract can also build trust and prolong business relationships between all participants, which in turn promotes sustainability of business practices. The act of acting together enables each participant to feel empowered into advancing ones ethical reputation and at the same time protecting the sustainability of business and each participant's well-being. In other words, CSR can be more than just the image of an outsourcer. An outsourcer's engagement in CSR would give better value to its reputation. The association of being an ethical outsourcer engaging in ethical outsourcing appeals more to consumers. Ethical outsourcing is more than just the promotion of fair trade products. It is making sure that every stage of the chain of production is being looked after from the suppliers (e.g. farmers) to the manufacturers (e.g. factory workers) to the logistics (e.g. warehouse operators and drivers) and finally to the retailers (e.g. store operators or service providers). Therefore, ethical outsourcing is more than just a label. It is the act of ethical outsourcing that promotes the reputation of all of outsourcing's participants.

Leaders of organizations can choose to empower themselves with the act of acting together in outsourcing. Practicing CSR does not have to be a mandatory act requiring state intervention. It could start in the way business leaders make agreements with partners.

\section{FUTURE RESEARCH DIRECTIONS}

Business leaders can empower themselves and their organizations through having all participants on board on their outsourcing projects. A multi-lateral agreement incorporating a code of conduct with all participants ensures a shared responsibility because each participant adopts the obligations and is expected to perform them. A multi-lateral agreement also instigates a dialogue between all participants allowing the sharing of knowledge and joint problem-solving. Large projects such as the Global Business Coalition function on prioritizing stakeholders' interests and devising solutions that achieve profitability and sustainability (Levine, 2009).

Financial projects such as the ones in project finance have successfully turned stakeholders' interests into economic performance gains through CSR practices (Eisenbach, Schiereck, Trillig, \& Von Flotow, 2013). Projects which are funded by the Equator Principles Financial Institutions (EPFIs) bind their participants with an environmental code of conduct called the Equator Principles (EP). The EPFIs have certainly raised environmental and sustainability awareness in potential participants by applying their codes of conduct when making funding applications.

Regulation in the form of labor laws or contract laws should also adopt the EP model. The future directions for this idea would be in the following: - (1) how a multilateral outsourcing contract would look if all the outsourcing participants were parties to it. (2) If participants such as suppliers, labor representatives and the auditor would have a say on the terms and conditions of a contract, it would be interesting to discover what the CSR focus would be. (3) It would be interesting to discover 
the efficacy of knowledge sharing and joint solution-finding in the light of sharing of risks between all participants and also in the light of the cost of production. (4) And finally, it would be interesting to discover the extent of ethical outsourcing's impact on the participants' reputation and consumer appeal.

With big events approaching such as the 2016 Olympics in Rio and the 2022 World Cup in Qatar, the exploitation of labor in construction and in the manufacturing of merchandises will proliferate if business leaders do not take action.

\section{CONCLUSION}

Empowering organizations through the act of acting together is essential for CSR practices. Business leaders ought to take the initiation of empowerment onto them by taking ownership over CSR practices. As it is suggested in this chapter, ethical outsourcing is achievable with the inclusion of all participants in outsourcing. Business leaders must exhibit voluntarism in making a multi-lateral outsourcing agreement involving all participants. CSR practices are better understood when undertaken by all participants through knowledge sharing and joint solution-finding. CSR practices are then shared by all participants. This method goes beyond outsourcing's current legal requirement. This method also goes beyond CSR's current practice, which is predominantly one enterprise's project acting alone. In summary, ethical outsourcing and the practice of CSR can be achieved through the empowerment of organizations in three steps. First, it requires the inclusion of all participants in a joint activity. Second, all participants must agree to enter into a multi-lateral agreement (as opposed to a bilateral one). Third, the voluntarism of each participant practicing CSR is strengthened by the peer-to-peer demands to fulfill these obligations.

\section{REFERENCES}

Aguilera, R.V., Williams, C.A., \& Ganapath, J. (2007). Putting the S back in Corporate Social Responsibility: A Multilevel Theory of Social Change in Organizations. Academy of Management Review, 32(3), 836-63.

Ang, Y. S. (2012). Solutions to Outsourcing Abuses: The Creation of Collective Obligations through Multilateral Contracts. Unpublished Doctoral Thesis, University of Birmingham, United Kingdom.

Ang, Y. S. (2014). Outsource to Asia: How Multilateral Corporations Legitimately Forget Corporate Social Responsibility. In K. C. P. Low, Idowu, S., \& Ang, S., L. (Eds.), Corporate Social Responsibility in Asia: Practice and Experience. (pp. 165-172). Springer

Apple Supplier Responsibility. (2014). Progress Report. Retrieved from http://images.apple.com/supplier-responsibility/pdf/Apple_SR_2014_Progress_Report.pdf

BBC News. (2013, April 25). Dhaka Building Collapse: Dozens Found Alive in Rubble. Retrieved from http://www.bbc.co.uk/news/world-asia-22299929

BBC News. (2010, May 28). Foxconn Suicides: 'Workers Feel Quite Lonely. Retrieved from http://www.bbc.co.uk/news/10182824

Bratman, M. (1999). Faces of Intention: Selected Essays on Intention and Agency. Cambridge, UK: Cambridge University Press.

Daily Mail Reporter. (2011, May 01). You are NOT Allowed to Commit Suicide: Workers in Chinese iPad Factories Forced to Sign Pledges. Retrieved from http://www.dailymail.co.uk/news/article1382396/Workers-Chinese-Apple-factories-forced-sign-pledges-commit-suicide.html

Doe v. Wal-Mart Stores, Inc. [2007]. United States District Court for the Central District of California pp. 1-13. 
Doe v. Wal-Mart Stores, Inc. [2009]. United States Court of Appeals pp. 8611-8625.

Drake v. IPOSOS Mori UK Ltd. [2012]. UKEAT/0604//11/ZT (Transcript).

Drexhage, J., \& Murphy, D. (2010). Sustainable Development: From Brundtland to Rio 2012. United Nations Headquarters, New York. Retrieved from

http://www.un.org/wcm/webdav/site/climatechange/shared/gsp/docs/GSP1-

6_Background\%20on\%20Sustainable\%20Devt.pdf

Eisenbach, S., Schiereck, D., Trillig, J., \& Von Flotow, P. (2013). Sustainable Project Finance, the Adoption of the Equator Principles and Shareholder Value Effects. Business Strategy and the Environment DOI 10.1002/bse.1789.

Engineering News-Records. (2013, July 05). Tragic Bangladesh Collapse Reveals Rampant Substandard, Illegal Construction. Retrieved from

http://enr.construction.com/buildings/building_types/2013/0513-Tragic-Bangladesh-Collapse-

$\underline{\text { Reveals-Substandard-Illegal-Construction.asp }}$

European Commission, (2011). A Renewed EU Strategy 2011-14 for Corporate Social Responsibility.Communication from the Commission to the European Parliament, Council, the European Economic and Social Committee and the Committee of the Regions, 681. Retrieved from http://eur-lex.europa.eu/LexUriServ/LexUriServ.do?uri=COM:2011:0681:FIN:EN:PDF

Gilbert, M. (1992). On Social Facts. Princeton, New Jersey: Princeton University Press.

Gilbert, M. (2008). A Theory of Political Obligation. Oxford, UK: Oxford University Press.

Hopkins, M. (2007). Corporate Social Responsibility \& International Development: Is Business the Solution? London, UK: Earthscan.

Ismail, A., Mohamed, H. A., Sulaiman, A. Z. \& Yusuf, M. H. (2011).An Empirical Study of the Relationship between Transformation Leadership, Empowerment and Organizational Commitment. Business and Economic Research, 1(2), 89-107.

Levine, J., (2009). Industry-Wide Coordination through Collaborative Planning Sessions is Changing the Way Companies take on Health in Partnerships with Contractors. GBC: Collective Supply Chain Action. Retrieved from http://www.gbchealth.org/files/Collective\%20Supply\%20Chain\%20Action.pdf

Milberg, W. \& Winkler, D. (2013). Outsourcing Economics: Global Value Chains in Capitalist Development. UK: Cambridge University Press.

Money Watch. (2013, August 07). What Happened after the Foxconn Suicides. Retrieved from http://www.cbsnews.com/8301-505124_162-57597168/what-happened-after-the-foxconn-suicides/

Oxfam (2013, April 26). Oxfam Reaction to Savar Building Collapse in Dhaka, Bangladesh. Retrieved fromhttp://www.oxfam.org.uk/media-centre/press-releases/2013/04/oxfam-reaction-to-thesavar-building-collapse-in-dhaka-bangladesh

Patently Apple. (2013, May 18). Sadly, More Suicides from Foxconn Factory have been Reported. Retrieved from http://www.patentlyapple.com/patently-apple/2013/05/sadly-more-suicides-fromfoxconn-factory-have-been-reported.html

Primark Penny's Supplier Code of Conduct. (2011). Retrieved from http://www.primarkethicaltrading.co.uk/file.axd?pointerid=67f71 f672a1145c39c1f7cacbafa5a42 
Sydney Morning Herald. (2012, December 27). Conditions Improving for Workers in China's Electronics Factories. Retrieved from http://www.smh.com.au/business/conditions-improving-forworkers-in-chinas-electronics-factories-20121227-2bxg8.html

The Guardian. (2013, August 02). The Woman who Nearly Died Making Your iPad. Retrieved from http://www.theguardian.com/commentisfree/2013/aug/05/woman-nearly-died-making-ipad

The Guardian. (2013, October 24). Primark Offers Long-Term Compensation to Rana Plaza Factory Collapse Victims. Retrieved from http://www.theguardian.com/world/2013/oct/24/primarkcompensation-rana-plaza-factory-collapse-bangladesh

Willcocks, L., P., Cullen, S., \& Craig, A. (2011). The Outsourcing Enterprise: From Cost Management to Collaborative Innovation. New York, US: Palgrave Macmillan.

\section{KEY TERMS AND DEFINITIONS}

Act of acting together: a concept taken from Margaret Gilbert who suggests that the participation of all in a task is crucial.

Ethical outsourcing: to take the interests of all participants into consideration. It prioritizes CSR's voluntarism and the active participation of all of outsourcing's participants to minimize outsourcing abuses through knowledge sharing and joint-solution finding.

Joint action: when two or more parties agreed to undertake a task together.

Laborers: include the employees and the casual workers of the outsourcer and the outsourced partner.

Legitimate Forgetting: the forgetting by all participants in a joint action of agreed or promised task.

Meshing of Plans: the planning and coordinating of individuals that makes a joint action workable.

Outsourcing: a process whereby an outsourcer sub-contracts its tasks onto an outsourced partner.

Participants: those who are engaged in the process of outsourcing which include the outsourcer, the outsourced partner, the suppliers, laborers, independent auditors and also perhaps trade unions. 